\title{
Four-Hydroxyphenylpyruvic Acid Oxidase Deficiency with Normal Fumarylacetoacetase: a New Variant Form of Hereditary Hypertyrosinemia
}

\author{
FUMIO ENDO, ${ }^{(32)}$ AKITO KITANO, ITSUKO UEHARA, NORIYUKI NAGATA, ICHIRO MATSUDA, \\ TOSHIHIRO SHINKA, TOMIKO KUHARA, AND ISAMU MATSUMOTO \\ Department of Pediatrics, Kumamoto University Medical School, 860, Kumamoto, Japan [F.E., A.K., I.U., N.N., \\ I.M.J and Research Institute of Medical Mass Spectrometry, Kurume University School of Medicine, \\ 830, Kurume, Japan T.S., T.K., I.M.J
}

\begin{abstract}
Summary
Enzymatic studies on the liver of an infant are described-a case of hypertyrosinemia without hepatic dysfunction. His parents were siblings and the mother had hypertyrosinemia. Excessive amounts of 4-hydroxyphenylpyruvic acid (pHPP), 4-hydroxyphenylacetic acid (pHPL), and 4-hydroxyphenylacetic acid (pHPA) were found to be excreted in the patient's urine as well as in the urine of the mother and the inhibitor of porphobilinogen synthetase, was not found. Soluble tyrosine aminotransferase (s-TAT), separated from that of the mitochondrial form (m-TAT) by DE 52 column chromatography, was normal in the patient's liver, both quantitatively and qualitatively. The activities of fumarylacetoacetase in the patient's liver and in the peripheral leucocytes from the parents were normal. The activity of PHPP oxidase in the patient's liver was approximately $5 \%$ of the control and the enzyme had a high $\mathrm{Km}$ value for pHPP (controls: $0.06 \pm 0.01 \mathrm{mM}$, patient: $0.23 \pm$ $0.03 \mathrm{mM}$ ). From these results, the patient was thought to be different from previously described types of tyrosinemia and perhaps representative of a new variant form.

This is the first report concerning 4-hydroxyphenylpyruvic acid oxidase deficiency alone. Mild metal retardation and mild hypertyrosinemia may be offered as typical clinical features of the disease.
\end{abstract}

\section{Abbreviations}

CAT, computerized axial tomography 2,4-DNPH, 2,4-dinitrophenylhydrazine GC/MS, gas chromatography-mass spectrometry GOT, aspartate aminotransferase MGOT, mitochondrial aspartate aminotransferase SGOT, cystosolic aspartate aminotransferase GPT, glutamic pyruvic transaminase pHPA, 4-hydroxyphenylacetic acid pHPL, 4-hydroxyphenyllactic acid pHPP, 4-hydroxyphenylpyruvic acid PALP, pyridoxal-5-phosphate TAT, tyrosine aminotransferase M-TAT, mitochondrial tyrosine aminotransferase S-TAT, soluble tyrosine aminotransferase UV, ultraviolet

There are two types of hereditary tyrosinemia. Type I is characterized by liver and renal tubular dysfunctions $(13,21)$, whereas type II is associated with mental retardation, eye and skin lesions, and microcephalus $(17,21)$. Patients belonging to either of these two types excrete a considerable amount of 4-hydroxyphenylpy- ruvic acid (pHPP), 4-hydroxyphenyllactic acid (pHPL) and 4hydroxyphenylacetic acid (pHPA) in their urine $(17,21)$. Although it is thought to be a secondary defect (3), pHPP oxidase in the liver was found to be reduced in type I patients (20). Then, Lindblad et. al. (24) found that the type I patients excreted succinylacetone into their urine, which was probably derived from maleylacetoacetate or fumarylacetoacetate. They suggested that the fumarylacetoacetase was defective in the liver with this disease (24). This view was confirmed by Fällström et. al. (10). With regards to type II, Fellman et. al. (11) clearly demonstrated the defective enzyme as being the soluble tyrosine aminotransferase (s-TAT). Later reports also confirmed this fact $(5,22)$.

We describe two cases of tyrosinemia, a male infant and his mother whose clinical and biochemical findings are distinct from those of hitherto reported types of hereditary tyrosinemia.

\section{CASE REPORT}

Our patient was born at full-term after normal pregnancy and his birth weight was $4050 \mathrm{~g}$. His parents were siblings. He was suffering from pneumonia and was admitted to a local hospital when he was 21 days old. At that time, he was also noted to have convulsions. The infection was treated with antibiotics but the neurologic findings did not improve. Hypertyrosinemia $(21.6 \mathrm{mg} /$ dl) was found at the age of 29 days by the dry blood screening test, and was not improved by oral administration of vitamin $\mathrm{C}$ ( $500 \mathrm{mg} /$ day). The infant was referred to the Department of Pediatrics, Kumamoto University Hospital at the age of 46 days for further investigation and treatment. On physical examination, the liver was palpable $(0.5 \mathrm{~cm}$ under costal margin $)$. Eyes and skin were normal. His consciousness was unclear and seizures resembling infantile spasms occurred several times per day. The background activity of the electroencephalogram was suppressed and single spike or polyspikes were observed on the left parietal or occipital areas. A brain CAT scan revealed mild brain atrophy. Normal laboratory values included peripheral blood counts, serum protein, bilirubin, phosphorus, calcium, and serum aspartate aminotransferase (GOT) and GPT activities. Urine analysis was normal except for the Milon test and 2,4-DNPH reaction, which were strongly positive. With an amino acid autoanalyzer, the patient's blood tyrosine level was $11.6 \mathrm{mg} / \mathrm{dl}$, but other amino acid levels, including methionine, were normal. Increased amounts of serine, glycine, histidine, and tyrosine were excreted in his urine. After the administration of low phenylalanine and low tyrosine milk ( $30 \mathrm{mg} / \mathrm{kg} /$ day), the blood tyrosine level decreased to $1.5-2.1 \mathrm{mg} / \mathrm{dl}$; however, the neurologic symptoms were not improved. When the tyrosine intake was increased to $100 \mathrm{mg} / \mathrm{kg} /$ day, the blood tyrosine level also rose to $12.6 \mathrm{mg} / \mathrm{dl}$. The blood 
tyrosine level was maintained around $10 \mathrm{mg} / \mathrm{dl}$ by administering $70 \mathrm{mg} / \mathrm{kg} /$ day of tyrosine and phenylalanine. At the age of 75 days, he was asphyxiated accidentally and died on the 105th day. During the clinical course, no evidence of liver dysfunction was observed. Histologic examination of the liver showed no hepatocellular damage other than mild fatty infiltration.

His father (24 years of age, elder brother of the mother) had a normal mental status and normal blood tyrosine level, whereas the mother (2l years of age) had mild mental retardation (IQ of approximately 80 ) and an elevated blood tyrosine level $(6.1 \mathrm{mg} /$ di). Their physical examinations were normal. Their routine laboratory studies, including liver function tests, were all normal except for the Milon test and 2,4-DNPH reaction of the mother's urine, which were positive. Another son of the mother (3 years of age), whose father was an unrelated person, was well developed. Informed consent was obtained from the parents for all the following investigations.

\section{MATERIALS AND METHODS}

DE 52 was purchased from Whatman Ltd. (Kent, England), Sephadex G-25 from Pharmacia Fine Chemicals (Uppsula, Sweden) and Dowex $50 \times 8\left(\mathrm{H}^{+}\right.$form) from Muromachi Kagaku Kaisha, Ltd. (Tokyo, Japan). 4-Hydroxyphenylpyruvic acid, homogentisic acid, 2,6-dichlorophenolindophenol and $\alpha, \alpha^{\prime}$-dipyridyl were obtained from Sigma Chemical Company (St. Louis, MO, U.S.A.). Amino acids, $\alpha$-ketoglutarate and $\beta$-phenethylamine were purchased from Wako Pure Chemicals (Osaka, Japan). $\delta$-amino levulinic acid, Erlich reagent, diethyldithiocarbamic acid and pyridoxal 5-Phosphate (PALP) were obtained from Nakarai Chemicals Ltd. (Kyoto, Japan). Maleate dehydrogenase, catalase, $\mathrm{L}$-amino acid oxidase, and nicotinamide adenine dinucleotide were obtained from Boehringar Mannhaim Yamanouchi K. K. (Tokyo, Japan).

1- $\left[{ }^{14} \mathrm{C}\right]-\mathrm{T}$ yrosine was obtained from New England Nuclear (Boston, MA, U.S.A.). $1-\left[{ }^{14} \mathrm{C}\right]$-pHPP was prepared daily by the method of Lindblad (23). Fumarylacetoacetate was prepared principally according to the procedure of Ravdin and Crandall (29) as follows: homogentisic acid oxidase was prepared from Wister strain rat liver according to the method of Edward and Knox (7) through step three. The enzyme was incubated with $1 \mathrm{mM}$ of homogentisic acid at $37^{\circ} \mathrm{C}$ for $30 \mathrm{~min}$ in $10 \mathrm{mM}$ of sodium carbonate, $\mathrm{pH} 6.0$, under $95 \% \mathrm{O}_{2}$ and $5 \% \mathrm{CO}_{2}$. The reaction was stopped by the addition of perchloric acid to a final concentration of $3 \%$. The fumarylacetoacetate formed was purified by the method of Ravdin and Crandall (29) through the ether extraction method. The material obtained was stored at $-70^{\circ} \mathrm{C}$ before use.

Anti-rat-tyrosine-transaminase-rabbit serum was kindly supplied by Dr. Towatari and Dr. Katunuma, Department of Enzyme Chemistry, Institute for Enzyme Research, Tokushima University Medical School.

Enzyme assay: Aspartate aminotransferase (GOT) was measured by the method of Karmen (16). Mitochondrial GOT (mGOT) was measured after the elimination of the cytosolic-GOT (s-GOT) using a commercially available kit (Eiken Kagaku, Tokyo, Japan) as previously described (27). Tyrosine aminotransferase (TAT) was measured by the method of Diamondstone (6). The radiochemical assay of pHPP oxidase was carried out by the method of Lindblad (23) with slight modifications. The reaction mixture contained $0.1 \mathrm{mM} 1-\left[{ }^{14} \mathrm{C}\right]-\mathrm{pHPP}(0.02 \mu \mathrm{Ci} /$ assay $), 10 \mathrm{mM}$ reduced glutathione, $1.5 \mathrm{mM}$ 2,6-dichlorophenolindophenol, 0.5 $\mathrm{mM} \alpha, \alpha^{\prime}$-dipyridyl, $15 \mathrm{mg} / \mathrm{ml}$ catalase, $0.1 \mathrm{M}$ potassium phosphate buffer, $\mathrm{pH} 6.5$ and an appropriate amount of the enzyme. The total amount of the reaction mixture was scaled down to $0.5 \mathrm{ml}$ and the reaction time was $15 \mathrm{~min}$, unless otherwise stated. The reaction was stopped by the addition of $1 \mathrm{ml}$ of $0.5 \mathrm{M}$ potassium monophosphate containing $30 \mathrm{mM}$ diethyldithiocarbamic acid and the incubation was continued to collect $\left[{ }^{14} \mathrm{CO}_{2}\right]$ for $15 \mathrm{~min}$. Released $\left[{ }^{14} \mathrm{CO}_{2}\right]$ during the incubation was collected in a piece of filter paper which contained $50 \mu 1$ of $\beta$-phenethylamine $(25 \%$ in ethanol, $v / v)$. The radioactivity of the paper was counted by using a Beckman Liquid Scintillation Counter. Fumarylacetoacetase was measured principally by the method of Edwards and Knox (8) as follows: the reaction mixture contained $0.1 \mathrm{M}$ sodium phosphate buffer, $\mathrm{pH} 7.5$ and an appropriate amount of enzyme in a total volume of $0.495 \mathrm{ml}$. The mixture was preincubated in a cuvette, which was maintained at $37^{\circ} \mathrm{C}$ for $5 \mathrm{~min}$ and the reaction was started by the addition of $5 \mu \mathrm{l}$ of the substrate solution. A decrease of the optical density at $330 \mathrm{~nm}$ was recorded. The final substrate concentration was $0.05 \mathrm{mM}$. The molecular extinction coefficient of fumarylacetoacetate used was $13.5 \times 10^{3}$. Porphobilinogen synthetase was assayed by the method of Collier (4). The inhibition of porphobilinogen synthetase by urine was tested by the addition of urine samples into the reaction mixture at the start of the preincubation, according to the description of Gray et. al. (14). Protein was measured by the method of Lowry et. al. (25) using bovine serum albumin as a standard.

Tissue preparation. The liver obtained after the autopsy was stored at $-70^{\circ} \mathrm{C}$ before use. The frozen liver was homogenized by using a Potter-Elvejem glass-teflon homogenizer with the following different buffers: $10 \mathrm{mM}$ potassium phosphate buffer, $\mathrm{pH} 7.4$, was used for the assay of TAT; $0.1 \mathrm{M}$ sodium phosphate buffer,

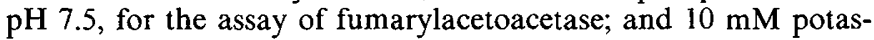
sium phosphate buffer, $\mathrm{pH} 6.5$, for the assay of $\mathrm{pHPP}$ oxidase.

Peripheral leucocytes were obtained by the modified method of Böyüm (2). The cells were disrupted by the freezing and thawing method. Peripheral erythrocytes were prepared by washing the heparinized blood, and the packed cells were hemolyzed by the addition of ice cold water. The hemolysate was used as a source of porphobilinogen synthetase.

Separation of cytosolic TAT (s-TAT) of liver: Because fractionation of soluble and mitochondrial fractions by centrifugation was impossible in the frozen liver, separation of s-TAT from mitochondrial TAT (m-TAT) was tested through a column chromatographic method. This method used frozen liver as well as fresh liver that was obtained by a surgical operation as reference material. The supernatant of frozen liver homogenate $(10,000 \times$ $g$ for $30 \mathrm{~min}$ ) was passed through a Sephadex G-25 column, which had been equilibrated with the same buffer. The eluate from the Sephadex G-25 column was applied to a DE 52 column $(2 \times 7$ $\mathrm{cm}$ ), which had been equilibrated with $10 \mathrm{mM}$ potassium phos-

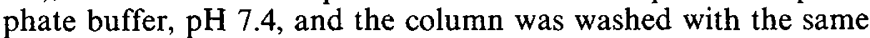
buffer. The unadsorbed fraction and the eluate were fractionated with a linear gradient of the buffer varying from $10-200 \mathrm{mM}$. In these fractionated solutions, the activities of GOT, m-GOT and TAT were measured. The same procedures were carried out in the soluble and mitochondrial fraction of the fresh liver.

Gas chromatography-mass spectrometry $(G C / M S)$ analysis of urine samples. GC/MS analysis of urine samples were carried out as.previously described (18)

\section{RESULTS}

Chromatography of the soluble and mitochondrial fractions of the fresh control liver on DE 52 yielded three peaks in which the first corresponded to $\mathrm{m}$-GOT and $\mathrm{m}$-TAT, the second to s-GOT, and the third to s-TAT (Fig. la, b). As is shown in Figure la, the second peak contained a weak activity of TAT. It was thought that s-GOT could transaminate tyrosine as well as aspartate. Chromatography of the supernatant $(10,000 \times \mathrm{g})$ of the frozen liver from the patient as well as the control, yielded three similar peaks (Fig. 1c, d). The s-GOT in the second peak and the s-TAT in the third peak reacted to anti s-GOT serum and anti s-TAT serum respectively, similar to the fractions of the fresh liver. These results indicate that the fractionation procedure on DE 52 resulted in a clear separation of m-TAT and s-TAT, even in the frozen liver. The activity of s-TAT of the patient and control livers are summarized in Table 1. Recovery rates of s-GOT and s-TAT from the DE 52 column were $85-89 \%$ and $76-86 \%$ respectively. Although s-TAT seemed to decrease in activity and as storage time $\left(-70^{\circ} \mathrm{C}\right)$ increased, the patient's s-TAT activity was actually not different from that of the corresponding control. Apparent $\mathrm{Km}$ 
values of s-TAT for tyrosine and PALP were similar in the patient and the controls (Table 1). The immunotitration curve of $\mathrm{s}-\mathrm{T}$ AT using anti s-TAT serum showed similar profiles in the patieni and the controls (Fig. 2).

In a preliminary study (9), the formation of homogentisic acid from pHPP was observed with the patient's liver homógenate by the colorimetric method of Fellman et. al. (11) (20\% of control). In the present study, the $\mathrm{pHPP}$ oxidase was assayed by the method of Lindblad (23), which measured the released $\left[{ }^{14} \mathrm{CO}_{2}\right]$ from 1$\left[{ }^{14} \mathrm{C}\right]-\mathrm{pHPP}$. Under the above described conditions, $25-35 \%$ of the substrate was oxidized by $25-75 \mu$ of supernatant (of $10,000 \times g$ ) the control liver homogenate $(10 \% \mathrm{w} / \mathrm{v})$. The liver $\mathrm{pHPP}$ oxidase was found to be stable when stored at $-70^{\circ} \mathrm{C}$ for at least 6 months. The enzyme activities of the patient and the controls are summarized in Table 2. No inhibitor of the enzyme activity was found in the supernatant of the liver from the patient. Heat stability of pHPP oxidase at $47^{\circ} \mathrm{C}, 51^{\circ} \mathrm{C}$, and $54^{\circ} \mathrm{C}$ was similar in the controls and the patient. The $\left[{ }^{14} \mathrm{CO}_{2}\right]$ production under different substrate concentrations was estimated in the patient and the control pHPP oxidase (Fig. 3a, b, c, d), and from these figures, apparent $\mathrm{Km}$ values were calculated. As shown in Table 2, the $\mathrm{Km}$ values for pHPP of the patient's enzyme was four times higher than those of the controls.

A visible UV spectrum of the purified fumarylacetoacetase indicated no contamination with the homogentisic acid, as was

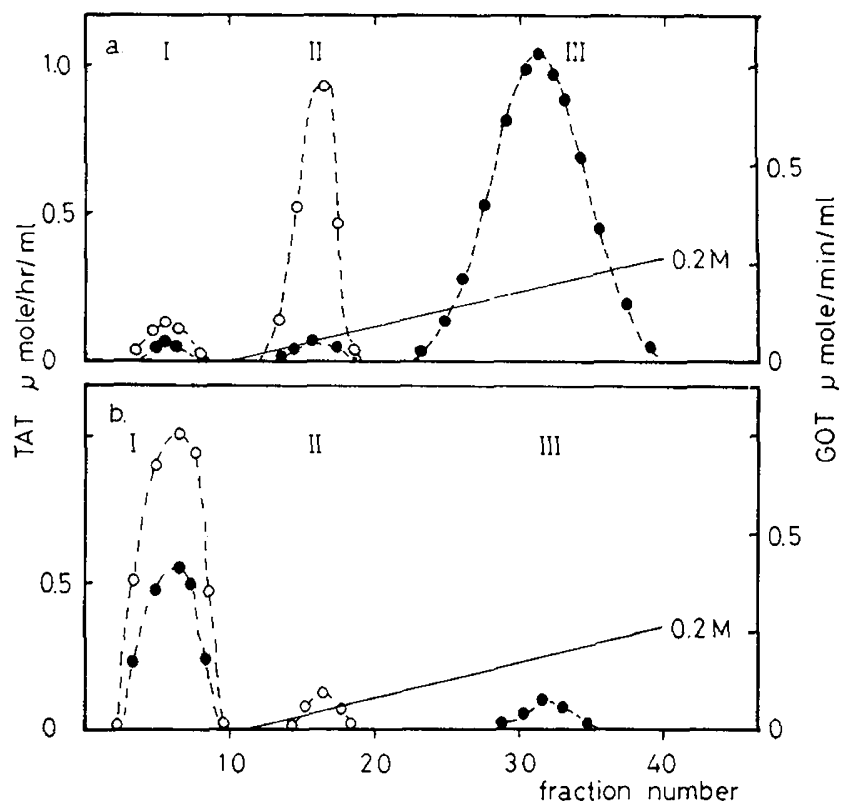

Fig. 1. Elution profile of tyrosine aminotransferase (TAT) and aspartate aminotransferase (GOT) activity from DE 52 column $(2 \times 8 \mathrm{~cm})$ chromatography. Open circles represent GOT activities and closed circles represent TAT activities. The eluate was fractionated by $6 \mathrm{ml} /$ tubes. Elution profiles of the soluble fraction of control liver $(a) ;(b)$ mitochondrial fraction; $(c)$ supernatant of control frozen liver; and $(d)$ supernatant of the patient's frozen liver are shown. In each instance, $5 \mathrm{~g}$ of wet liver tissue was used as starting material. shown by Ravdin and Crandall (29). The absorbance at $327 \mathrm{~nm}$, corresponding to fumarylacetoacetate, decreased in the mixture after the addition of the supernatant of liver homogenate $(10,000$ $\times g)$ as the incubation time increased. A similar reaction was observed when white blood cell lysate was substituted for the liver homogenate. A linear relationship was found between both the protein concentrations of the liver homogenate and leucocyte lysate to the reduction in fumarylacetoacetate. The enzyme, when kept below $-70^{\circ} \mathrm{C}$, was found to be stable for at least 6 months. Ninety-five percent of the liver enzyme existed in the soluble fraction and less than $5 \%$ in the mitochondrial fraction. Therefore, almost all the fumarylacetoacetase in the supernatant of the frozen liver was of the soluble fraction. The enzyme activities of the patient's liver and that of the parents' white blood cells were within the normal range (Table 3 ). Heat stability of the enzyme at $55^{\circ} \mathrm{C}$ was similar in the patient and the control livers $\left(\mathrm{T}_{1 / 2}, 5 \mathrm{~min}\right)$. The apparent $\mathrm{Km}$ values of the enzyme for fumarylacetoacetate were $2.5 \mu \mathrm{M}$ in the controls and the patient's liver.

The inhibitor of porphobilinogen synthetase in the urinu samples from the patient and his mother were examined at fasting and after tyrosine loading $(100 \mathrm{mg} / \mathrm{kg})$. No inhibiting activity was found in any of these samples.

As shown in Table 4, the patient and his mother excreted highly elevated amounts of pHPP, pHPA, and pHPL, respectively.

\section{DISCUSSION}

In the present study, it was shown that DE 52 column chromatography is capable of separating s-TAT from m-TAT of the frozen liver. The m-TAT and s-TAT of the patient's liver were fractionated and found to be normal in activity. In addition, the elution profile on the chromatography, apparent $\mathrm{Km}$ values for tyrosine and for PALP, and immunotitration curve of s-TAT were similar in the patient and the control. These results indicated that the disease is not likely due to TAT deficiency.

Studies on fumarylacetoacetase in the patient's liver resulted in normal activity and normal parameters of the enzyme, such as heat stability and apparent $\mathrm{Km}$ value. The presence of fumarylacetoacetase in the white blood cells was clearly shown in the present study, which was supported by a recent report (19). The observation is in conflict with the early report by Berger et. al. (1). The normal activity in the patient's liver and in the parents' leucocytes may indicate that the fumarylacetoacetase is not the involved enzyme in our case.

With regard to pHPP oxidase, the enzyme in the patient's liver was $5 \%$ of the control activity, and had a high $\mathrm{Km}$ value for pHPP. There was no substance inhibiting pHPP oxidase in the patient's liver supernatant. These results suggest that the nature of the enzyme in the patient's liver is altered by structural gene mutation.

These observations conflict with hitherto reported tyrosinemia, because both pHPP oxidase and fumarylacetoacetase were impaired in the type I disease (although it is still unclear which is a primary defect) and only cytosol tyrosine aminotransferase in the type II disease. The absence of the inhibitor of porphobilinogen synthetase in the urine again conflicts with the type I disease (14, 24 ); thus, the case might be offered as a new variant form of tyrosinemia. The absence of hepatorenal insufficiency and ocu-

Table 1. Soluble tyrosine aminotransferase (s-TAT) in liver

\begin{tabular}{|c|c|c|c|}
\hline & \multirow{2}{*}{$\begin{array}{c}\text { Activity of s-TAT } \\
(\mu \text { mole } / \mathrm{h} / \mathrm{g} \cdot \mathrm{protein})\end{array}$} & \multicolumn{2}{|c|}{$\mathrm{Km}$ values } \\
\hline & & PALP & Tyrosine \\
\hline Patient $\left(-70^{\circ} \mathrm{C}\right.$ for 1 month $)$ & 31.8 & $2.8 \mu \mathrm{M}$ & $0.87 \mathrm{mM}$ \\
\hline Control $\left(-70^{\circ} \mathrm{C} \text { for } 1 \text { month }\right)^{1}$ & 37.5 & $2.2 \mu \mathrm{M}$ & $0.87 \mathrm{mM}$ \\
\hline Control $\left(-70^{\circ} \mathrm{C} \text { for } 1 \text { month }\right)^{1}$ & 41.2 & $2.4 \mu \mathrm{M}$ & $0.90 \mathrm{mM}$ \\
\hline Control $\left(-70^{\circ} \mathrm{C} \text { for } 2 \text { weeks }\right)^{1}$ & 56.3 & & \\
\hline Control (Fresh sample) ${ }^{2}$ & 92.3 & & \\
\hline
\end{tabular}

\footnotetext{
${ }^{1}$ Livers were obtained from subjects without hepatic dysfunction, aged 3-11 months.

${ }^{2}$ Soluble fraction from fresh human liver.
} 


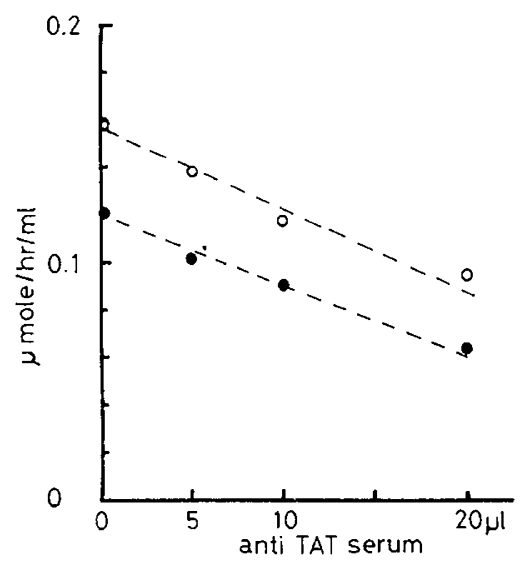

Fig. 2. Immunotitration curves of s-TAT from normal control $(O)$ and the patient (๑). $250 \mu$ l of enzyme preparation was incubated with various amounts of anti-rat-s-TAT serum at $25^{\circ} \mathrm{C}$ for $4 \mathrm{~h}$. After the centrifugation $(10,000 \times g$ for $30 \mathrm{~min})$ the activity in the supernatant was measured.

Table 2. 4-Hydroxyphenylpyruvic acid (pHPP) oxidase in liver

\begin{tabular}{lll}
\hline & $\mathrm{U} / \mathrm{g}$ protein & $\mathrm{Km}$ value for $\mathrm{pHPP}$ \\
\hline Patient & 0.45 & $0.23 \pm 0.03 \mathrm{mM}^{1}$ \\
Controls $^{3}$ & $4.2-13.6(n=4)$ & $0.06 \pm 0.01 \mathrm{mM}^{2}$ \\
\hline
\end{tabular}

'Mean \pm S.D. from three different assays.

${ }^{2}$ Mean \pm S.D. from four different samples.

${ }^{3}$ Controls are without hepatic dysfunction, aged 2-11 months.

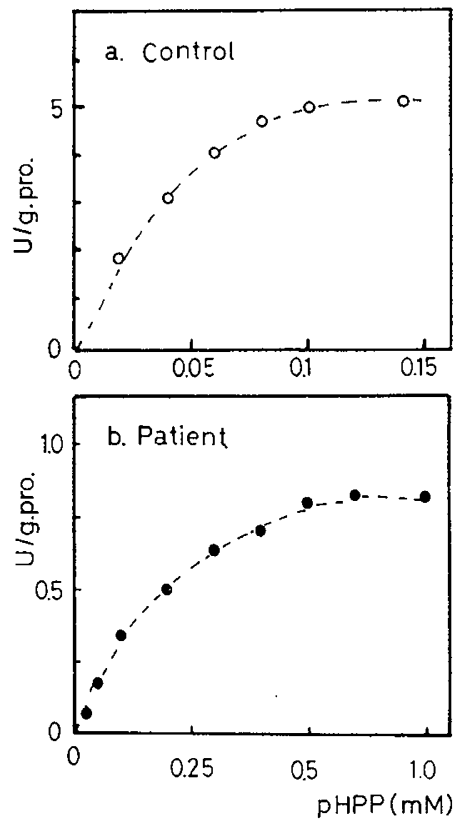

Fig. 3. Relationship of concentration of pHPP to velocity of the reaction under air. Enzymes were normal control liver supernatant $(O)$ and patient's liver supernatant (๑). Incubation time was $30 \mathrm{~min}$.

Table 3. Fumarylacetoacetase in liver and leucocytes

\begin{tabular}{lcc}
\hline & $\mathrm{U} / \mathrm{g}$ protein & $\mathrm{Km}$ value \\
\hline Patient liver & 7.2 & $2.5 \mu \mathrm{M}$ \\
Control liver $^{1}(n=4)$ & $7.0-16.2$ & $2.5 \mu \mathrm{M}(n=2)$ \\
& 3.6 & \\
Leucocytes from the mother & 4.1 & \\
Leucocytes from the father & $3.3-4.5$ & \\
Leucocytes from normal adult & & \\
$\quad(n=4)$ &
\end{tabular}

\footnotetext{
${ }^{\prime}$ Control livers were obtained from subjects without hepatic dysfunction, aged 2-11 months.
}

Table 4. The urinary excretion of 4-hydroxyphenylacetic acid (pHPA) 4-hydroxyphenyllactic acid ( $p H P L)$ and 4hydroxyphenylpyruvic acid ( $(\mathrm{HPP})$ in the patient and the mother ${ }^{1}$

\begin{tabular}{lcccc}
\hline & Patient & $\begin{array}{c}\text { Control } \\
\text { (infant) }\end{array}$ & Mother & $\begin{array}{c}\text { Control } \\
\text { (adult) }\end{array}$ \\
\hline pHPA $^{2}$ & 10.90 & $0.68 \pm 0.31$ & 3.98 & $0.36 \pm 0.22$ \\
pHPL $^{2}$ & 27.77 & UD $^{3}$ & 6.94 & UD \\
pHPP $^{2}$ & 21.73 & UD & 4.18 & UD \\
\hline
\end{tabular}

' The blood tyrosine levels of the patient and the mother are $12.6 \mathrm{mg}$ / $\mathrm{dl}$ and $6.0 \mathrm{mg} / \mathrm{dl}$, respectively.

${ }^{2}$ Gaschromatographic peak area relative to international standard IS(18).

${ }^{3} \mathrm{UD}$, undetectable.

lodermal lesions, which are typical clinical features of type I and type II disease $(13,17,21)$, respectively, also support this concept.

The present case existed in a particular situation, because he was a product of siblings. If the disease is inherited with an autosomal recessive trait, the mother and her brother, the father of the patient, are likely to be homozygous and heterozygous, respectively, because mental retardation in association with elevated blood tyrosine and increased urinary pHPP, pHPA, and pHPL at fasting were found in the mother but not in the father. Another possible aspect is that the disease was inherited by $\mathrm{X}$ linked trait, where the mother in heterozygote and the patient hemizygote; however, inspecting the particular situation of the family, we preferred to consider that the disease was inherited as an autosomal recessive trait.

It is probable that, the mother's features are of pHPP oxidase deficiency. She excreted considerable amounts of pHPP, pHPL, and pHPA in her urine at which time the blood tyrosine level was $6.0 \mathrm{mg} / \mathrm{dl}$ (Table 4). When tyrosine was administered to normal adults $(100 \mathrm{mg} / \mathrm{kg})$ the blood tyrosine level increased to $4.5-5.5$ $\mathrm{mg} / \mathrm{dl}$, and only trace amounts of pHPP and pHPL and a small amount of pHPA were excreted. The excretion of these materials from the mother was less than that of the infant. It may be due to the difference of protein intake and blood tyrosine level (12.6 mg/ $\mathrm{dl}$ in the infant) between the infant and the mother. She had neither liver dysfunction nor abnormality of renal tubular function. The clinical and biochemical features resembled those of the case of Medes (28). The inhibitor of porphobilinogen synthetase was absent in her urine and fumarylacetoacetase in her leucocytes was normal. These results differ from the usual type I tyrosinemia $(1,13,14,15,21,24)$. The elder brother of the patient, whose father was an unrelated person, was apparently normal at least until three years of age. Mild hypertyrosinemia, as observed in the mother, seemed to be harmless to the development of the fetus. Fellman et. al. (12) reported that the activity of pHPP oxidase in the human fetal liver and kidney was undetectable at least until $28 \mathrm{wk}$ of gestational age; thus, maternal hypertyrosinemia and fetal pHPP oxidase deficiency, especially in the early or midfetal life of the fetus, might have no adverse effects on intrauterine development. On the other hand, the adverse effects of hypertyrosinemia had been observed in transient hypertyrosinemia of newborns (26), although these effects were diminished with the reduction of blood tyrosine level (26).

In our case, the neurologic symptoms persisted even after the reduction of blood tyrosine level; therefore, these symptoms were not related to a high concentration of blood tyrosine level as observed in transient hypertyrosinemia of newborns. Although the mechanism of the development of neurologic symptoms is still unclear, it may have been augmented by the simultaneous presence of maternal and fetal hypertyrosinemia.

For a further understanding of the disease, the confirmation of the mutant enzyme in the mother remains to be established.

\section{REFERENCES AND NOTES}

1. Berger, R., Smit, G. P. A., Stoker-de Vries, S. A., Duran, M., Ketting, D., and Wadman, S. K.: Deficiency of fumarylacetoacetase in a patient with hereditary tyrosinemia. Clin. Clim. Acta, 114: 37 (1981). 
2. Böyüm, A.: Separation of leucocytes from blood and bone marrow. Scand. J. Clin. Lab. Invest. Suppl., 21: 77 (1968).

3. Carson, N. A. J., Biggart, J. D., Bittles, A. H., and Donovan, D. Hereditary tyrosinemia-clinical, enzymatic and pathological study of an infant with the acute form of the disease. Arch. Dis. Child., 5: 105 (1976).

4. Collier, H. B.: A study of the determination of 5-aminolevulinate hydro-lyase $(\delta$-aminolevulinate dehydratase) activity in hemolysates of human erythrocytes. Clin. Biochem., 4: 222 (1971).

5. deCroot, C. W., Dakshinamurti, K., Allan, L. and Haworth, J. C.: Defect in soluble tyrosine aminotransferase in skin fibroblasts of a patient with tyrosinemia. Pediatr. Res., 14: 896 (1980).

6. Diamondstone, T. I.: Assay of tryosine transaminase activity by conversion of $p$ hydroxyphenylpyruvate to p-hydroxyphenylbenzaldehyde. Ana. Biochem., 16: 395 (1966)

7. Edwards, S. W. and Knox, W. E.: Homogentisate oxidase from rat liver. In: Colowich, S. P. and Kaplan, N. O. eds. Methods Enzymology, Vol. 2 Academic Press, New York, pp 292-295 (1955).

8. Edwards, S. W. and Knox, W. E.: Fumarylacetoacetate hydrolase. In: Colowich, S. P. and Kaplan, N. O. eds. Methods in Enzymology, Vol 2 Academic Press, New York. pp 298-300 (1955).

9. Endo, F., Kitano, A., Uehara, I., Nagata, N. and Matsuda, I.: Hypertyrosinemia with an atypical clinical course. Proc. Jap. Soc. Med. Mass. Spec., 5: 154 (1980).

10 . Fällström, S. P., Lindblad, B., Lindsted, S., and Steen, G.: Hereditary tyrosinemia-fumarylacetoacetase deficiency. Pediatr. Res., 13: 78 (1979) abstract.

11. Fellman, J. H., Vanbellinghen, P. J., Jones, R. T., and Koler, R. D.: Soluble and mitochondrial form of tyrosine aminotransferase. Relationship to human tyrosinemia. Biochemistry, 8: 615 (1969).

12. Fellman, J. H., Fujita, T. S., and Roth, E. S.: Assay, properties and tissue distribution of p-hydroxyphenylpyruvate hydroxylase. Biochem. Biophys. Acta., 284: 90 (1972).

13. Gentz, J., Jagenburg, R., and Zetterstrom, R.: Tyrosinemia. An inborn error of tyrosine metabolism with cirrhosis of the liver and multiple renal tubular defects (de Toni-Debre-Fanconi syndrome). J. Pediatr., 66: 670 (1965).

14. Gray, R. G. G., Patrick, A. D., Preston, F. E., and Whitfield, M. F.: Acute hereditary tyrosinemia type I: Clinical, biochemical and hematological studies in twins. J. Inher. Metab. Dis., 4: 37 (1981).

15. Halvorsen, S., Helene Pande, Aagot Christie Loken and Gjessing, L. R.: Tyrosinosis. A study of 6 cases. Arch. Dis. Child., 41: 238 (1966)

16. Karmen, A.: A note on the spectrophotometric assay of Glutamic oxaloacetic transaminase in human blood serum. J. Clin. Invest., 34: 131 (1955).

17. Kennaway, N. G. and Buist, N. R. M.: Metabolic studies in a patient with hepatic cytosol tyrosine aminotransferase deficiency. Pediatr. Res., 5: 287 (1971).

18. Kuhara, T. and Matsumoto, I.: Studies on the urinary acidic metabolites from three patients with methylmalonic aciduria. Biomed. Mass Spectrom., 7: 424 (1980).

19. Kvittingen, E. A., Jellum, E., Stokke, O. and Halvorsen, S.: Studies on hereditary tyrosinemia. Pediatr. Res., 15: 1182 (1981).

20. Ladu, B. N.: The enzymatic deficiency in tyrosinemia. Amer. J. Dis. Child. 113: 54 (1967).

21. Ladu, B. N. and Gejessing, L. R.: Tyrosinosis and tyrosinemia. In: Stanburry, J. S., Wyngaarden, J. B. and Fredrickson, D. S. eds. The metabolic basis of inherited disease. McGraw-Hill, New York pp 256-267 (1978).

22. Lemonnier, F., Charpentier, C., Odievre, M., Larregve, M. and Lemonnier, A.: 'Tyrosine aminotransferase isoenzyme deficiency. J. Pediatr., 94: 931 (1979).

23. Lindblad, B.: Radiochemical assays for $\mathrm{p}-\mathrm{Hydroxyphenylpyruvate} \mathrm{hydroxylase}$ activity in human liver. Clin. Chim. Acta, 34: 113 (1971).

24. Lindblad, B., Lindstedt, S. and Steen, G.: On the enzymatic defects in hereditary tyrosinemia. Proc. Natl. Acad. Sci. USA., 74: 4641 (1977).

25. Lowry, O. H., Rosebrough, N. J., Farr, A. L., and Randall, R.: Protein measurement with the Folin phenol reagent. J. Biol. Chem., 193: 265 (1951)

26. Martin, H. P., Fisher, H. L., Martin, D. S. and Peter Chase, H.: The development of children with transient neonatal tyrosinemia. J. Pediatr., 84: 212 (1974).

27. Matsuda, I., Miyoshino, S., Miike, T., Nagata, N., Tamari, H., Taniguchi, N., Ohno, H., and Watanabe, H.: Mitochondrial fraction of serum glutamateoxaloacetic transaminase in Duchenne Muscular Dystrophy. Clin. Chim. Acta, 83: 231 (1978).

28. Medes, G.: A new error of tyrosine metabolism: Tyrosinosis. The intermediatry metabolism of tyrosine and phenylalanine. Biochem. J., 26: 917 (1932).

29: Ravdin, R. G. and Crandall, D. I.: The enzymatic conversion of hemogentisic acid to 4-fumarylacetoacetic acid. J. Biol. Chem., 189: 137 (1951).

30. The authors thank Professor N. Katunuma of the Department of Enzyme Chemistry, Institute for Enzyme Research, Tokushima University Medical School, for his kind help, Dr. T. Hamada of Department of Pathology, Kumamoto University Medical School, for the histological examination of the autopsied liver.

31. This investigation was supported by a Research Grant aided by the Ministry of Health and Welfare for the Research of Inborn Error and a Research Grant from the Ministry of Education of Japan.

32. Requests for reprints should be addressed to: Dr. Fumio Endo, Department of Pediatrics, Kumamoto University Medical School 860, Kumamoto, Japan.

33. Received for publication December 11, 1981.

34. Accepted for publication May 4, 1982. 